Forschende

Komplementärmedizin und

Klassische Naturheilkunde

\section{Contents of Forthcoming Issues - Themenvorschau}

\section{Editorials}

Case Report

Letter to the Editors
Welches Fachgebiet akademisieren wir derzeit eigentlich an den Universitäten? Ein Wort zum Terminologie-Wirrwarr! Melchart, D. (München)

Gedanken zur wissenschaftlichen Evaluation der Kinesiologie Sonderegger, L. (Zürich)

Impact of Ethanolic Lamiaceae Extracts on Herpesvirus Infectivity in Cell Culture Reichling, J.; Nolkemper, S. (Heidelberg); Stintzing, F.C. (Stuttgart/Bad Boll); Schnitzler, P. (Heidelberg)

An Exploratory Pilot Study to Design and Assess the Credibility of a Sham Kinesiology Treatment

Hall, S.; Lewith, G.; Brien, S.; Little, P. (Southampton)

Body Constitution Questionnaire for Yang-Xu. Part I: Development of the First Final Version

Su, Y.C.; Chen, L.L. (Taichung); Lin, J.S. (Taipei); Lin, J.D. (Taichung); Chang, C.H. (Chicago, IL); Liang, W.M.; Lai, J.S. (Taichung)

Klangmeditation in der onkologischen Rehabilitation:

Pilotstudie zu einer rezeptiven Gruppenmusiktherapie mit dem Monochord Rose, J.P.; Weis, J. (Freiburg i.Br.)

Gestaltungskurs fuir Krebspatienten in der ambulanten Nachsorge - psychische Belastung und Krankheitsverarbeitung der Teilnehmer Götze, H.; Geue, K.; Buttstädt, M.; Singer, S.; Schwarz, R. (Leipzig)

Treating Histiocytic Necrotizing Lymphadenitis with Chinese Herbs Wang, X.; Sang, X.; Wang, J. (Harbin); Zhou, J.; Qu, F. (Hangzhou); Burrows, E. (Brooklyn, NY)

A Review of the Literature in Applied and Specialised Kinesiology: A Reply McDowall, D.A. (Belconnen); Cuthbert, S. (Pueblo, CO) 